\title{
Acerca de la legilibilidad de la fotografía y El arte de visibilizar la pregunta (Koen Wessing)
}

\section{About the readability of the photography and $E /$ arte de visibilizar la pregunta (Koen Wessing)}

\author{
Mary Mac-Millan \\ Departamento de Literatura, Universidad Adolfo lbáñez. Viña del Mar, Chile. \\ mary.macmillan@uai.cl
}

\section{Resumen}

En una primera parte, este artículo se centra en las posibilidades de lectura que le competen a la fotografía. Para ello se postulan tres aproximaciones. En primer lugar, una lectura ingenua o sin contexto previo. En segundo lugar, una lectura contextualizada, tal y como lo entiende Peter Burke y una aproximación que, en tercer lugar, sigue los postulados de Didi-Huberman y Jacques Rancière, quienes hacen hincapié en una participación tanto emotiva como intelectual. En una segunda parte se piensan estas tres aproximaciones en la obra El arte de visibilizar la pregunta del fotógrafo Koen Wessing a partir de las fotografías de "Chile 1973".

Palabras clave: fotografía, lectura, implicación.

\begin{abstract}
On its first part, this article focuses on the possibilities of interpretation associated to photography. For that purpose, three approaches are postulated. First, the naive interpretation without previous context. Second, the contextualized interpretation, as Peter Burke understands it. The third approach follows the postulates of Didi-Huberman and Ranciere, who focus on an emotional and intellectual participation. On the second part, these three approaches are applied to the work El arte de visibilizar la pregunta, by Koen Wessing, focusing on the photographs of "Chile 1973".
\end{abstract}

Keywords: Photography, Interpretation, Implication. 


\section{Introducción}

El presente artículo surge a partir de una ponencia presentada en las Segundas Jornadas Internacionales de Literatura Comparada tituladas "Formas de escribir, ver y leer" . Retomo la propuesta sugerente de su título para interrogar sobre la forma de ver y, por lo tanto, de leer la imagen fotográfica. Según el crítico de arte Peter Burke, si bien las imágenes tienen por objeto comunicar, "[e]n otro sentido, en cambio, no nos dicen nada. Las imágenes son irremediablemente mudas” (43). ¿Cómo hacer hablar, entonces, correctamente esas imágenes mudas? La pregunta es, sin duda, vasta y ha tenido múltiples respuestas desde diversos enfoques teóricos. En este texto espacio me propongo sopesar -en primera instancia y siguiendo diversos autores- tres formas posibles de leer una imagen para, posteriormente, cotejar dichos modos en la obra de Koen Wessing, titulada Fotografía, El arte de visibilizar la pregunta con el fin de rastrear sus límites. Estos modos son: sin contextualización, con contextualización tradicional y mediante un dispositivo contextual.

\section{Tres modalidades de lectura}

\section{Primera modalidad de lectura: sin contextualización alguna}

Leer una imagen sin conocimientos previos puede llevar a lecturas antojadizas y proyecciones personales. Nos sirve de ejemplo el procedimiento llevado a cabo por el escritor argentino Julio Cortázar. Cortázar “juega” magistralmente con esta situación en su texto "Instrucciones para entender tres pinturas famosas"2. El escritor ironiza acerca de lecturas que, si bien apegadas a las imágenes -es decir, a elementos estructurales del "texto" - se desvían del todo de la referencialidad histórica/cultural de la imagen. Este procedimiento lo ejecuta en "El amor sagrado y el amor profano" de Tiziano, en "La dama del unicornio" de Rafael y en "Retrato de Enrique viII de Inglaterra" de Holbein ${ }^{3}$. Me concentro en un solo ejemplo, el cuadro de Tiziano (fig. 1), sobre el cual declara:

Esta detestable pintura representa un velorio a orillas del Jordán. Pocas veces la torpeza de un pintor pudo aludir con más abyección a las esperanzas del mundo en un Mesías que brilla por su ausencia; ausente del cuadro que es el mundo, brilla horriblemente en el obsceno bostezo del sarcófago de mármol, mientras el ángel encargado de proclamar la resurrección de su carne patibularia espera

1 Organizadas por la Universidad Adolfo Ibáñez en Santiago de Chile los días 11 y 12 de noviembre de 2014.

2 En Historias de cronopios y de famas, en el segmento titulado "Manual de Instrucciones".

3 Si bien Cortázar se centra en la lectura de pinturas, y en este artículo se piensa la imagen fotográfica, la problemática es común para ambos tipos de imágenes. 
FIGURA 1

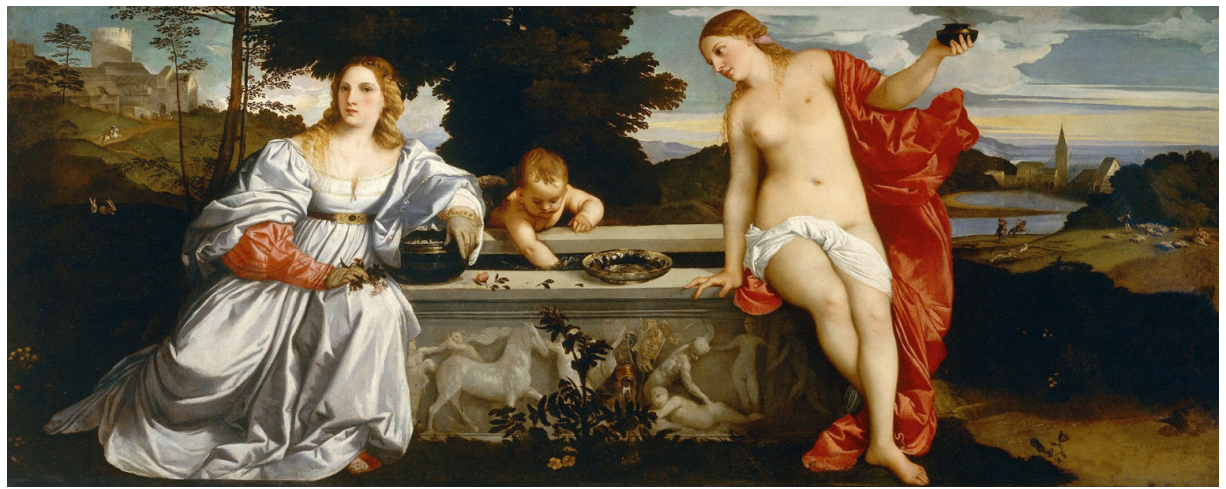

Amor sacro y amor profano (1515). Tiziano. Óleo sobre lienzo, 118 x 279 cm. Galería Borghese, Roma, Italia.

inobjetable que se cumplan los signos. No será necesario explicar que el ángel es la figura desnuda, prostituyéndose en su gordura maravillosa, y que se ha disfrazado de Magdalena, irrisión de irrisiones a la hora en que la verdadera Magdalena avanza por el camino (donde en cambio crece la venenosa blasfemia de dos conejos). El niño que mete la mano en el sarcófago es Lutero, o sea el Diablo (18).

En esta lectura irónica, Cortázar, desatendiendo la contextualización del título (amor profano/amor sagrado), introduce una lectura de extrema arbitrariedad sobre de los elementos que componen la imagen: la fuente de agua es un sarcófago, la diosa es Magdalena, del niño dirá “que es Lutero, o sea, el diablo", y el cuadro total se lee como una ceremonia fúnebre, como un entierro. La contraparte de esta lectura apunta a que en la escena se ha identificado tradicionalmente a la mujer vestida como a Venus (amor sagrado) y a la mujer desnuda como al amor profano y al niño desnudo como a Cupido. La lectura de Cortázar - por muy descabellada que parezca- se origina en elementos que están en la imagen, sin embargo, queda en evidencia que la imagen no se basta a sí misma. Ahora bien, si lo miramos más de cerca, el juego de Cortázar se puede pensar de otra manera: mediante dicha caricatura no hace más que poner en evidencia que inclusive las lecturas "cultas", basadas en un estudio tanto iconográfico como iconológico ${ }^{4}$ también pueden poseer un alto grado de arbitrariedad, puesto que surgen de una convención. Por cierto, las tres lecturas antojadizas que Cortázar realiza con cuadros famosos se insertan significativamente al interior del segmento

4 Peter Burke distingue tres niveles de lectura de imágenes: la descripción preiconográfica (el reconocimiento de los objetos presentes), el nivel iconográfico (relacionada con el significado tradicional de los objetos representados) y el nivel iconológico (corresponde a la interpretación epocal). Estos tres niveles se corresponden con lo que solemos entender por "nivel literal o gramatical", "nivel histórico" y "nivel cultural" (43-6). 
denominado "Manual de Instrucciones". Las “instrucciones” más conocidas para la mayoría de los lectores son: "Instrucciones para llorar" y, por supuesto, las hilarantes "Instrucciones para subir una escalera". No es coincidencia esta clasificación. Surge de inmediato en el lector la pregunta acerca de la relación entre "llorar", "subir una escalera" y "entender tres cuadros famosos". Pues se hace evidente la ironía en el caso de llorar y subir una escalera debido a que son actividades para las que no necesitamos instrucciones, ya que se realizan de modo espontáneo y natural. Pues bien, a lo que apunta Cortázar es, precisamente, a mostrar que ni el llanto ni el subir escaleras son tan naturales como pensamos: detrás de cada gesto se anida un aprendizaje social y normativo. Si hacemos ahora la conexión con la lectura de imágenes, nuevamente se refuerza la ironía: creemos entender los cuadros famosos, hemos crecido escuchando determinadas lecturas sobre ellos. Sin embargo, estas lecturas no son naturales y las tres exageraciones de Cortázar actúan como caricaturas que ponen en evidencia dicho elemento: pueden haber más lecturas y los criterios de validez son siempre discutibles, no existe tal naturalidad.

\section{Segunda modalidad: contextualización}

Si Cortázar llevaba a un extremo la posibilidad de leer una imagen sin contexto -juego que en su caso expone de rebote el elemento arbitrario-cultural subyacente en toda lectura- veamos ahora brevemente la contra postura: la necesidad de contextualización de toda imagen. Expondremos sucintamente los postulados de Peter Burke en Visto y no visto. El uso de la imagen como documento histórico. Burke inicia su trabajo sentando la dificultad de lectura que le sería propia a la fotografía, más que a un texto escrito: "Las imágenes son testigos mudos y resulta difícil traducir a palabras el testimonio que nos ofrecen" (18). Si las imágenes son mudas, entonces es tarea del lector el "hacerlas hablar". En esta tarea se corren algunos peligros, y surge la duda acerca de la fiabilidad de la fotografía en tanto mensajera. Sabida es la discusión -en la cual no entraremos ahora- sobre la capacidad de falsear o retocar la realidad mediante la imagen ${ }^{5}$. Burke llega a plantear algunas medidas generales para reducir el margen de error en la lectura de la imagen, aunque prudentemente aclara: "no como principios universales, sino simplemente como un resumen de los problemas de interpretación que suelen aparecer una y otra vez" (239). De ese modo, propone a manera de método, algunas medidas aplicables.

5 En relación a famosas fotografías “intervenidas”, Joan Fontcuberta, en El beso de Judas. Fotografía y verdad, cita algunos casos memorables: "Dorothea Lange, autora del retrato Migrant Mother, todo un símbolo del período de la Depresión estadounidense; Robert Capa con su impactante toma del miliciano republicano muerto en la guerra civil española; Agusti Centelles con sus guardias de asalto apostados tras un caballo muerto; Joe Roesenthal que inmortalizó el donaire de los marines ondeando la bandera de las barras y estrellas en el punto más elevado de la isla de Iwo Jima; Alfred Eisenstaedt con su histórico beso en Times Squareentte un marinero y una enfermera para celebrar el fin de la Segunda Guerra Mundial, o Robert Doisneau con otro beso histórico, su Le baiser de l'Hotel de Ville" (128). 
La primera medida: "El testimonio de las imágenes debe ser situado en un contexto, o mejor dicho, en una serie de contextos (cultural, político, material, etc.)" (239). Queda claro que por contexto Burke entiende un concepto bastante amplio: además de los mencionados aspectos culturales, políticos y materiales, añade las convenciones artísticas de representación junto con los intereses del artista. Por "convenciones artísticas de representación" se refiere a que en cada época existe un determinado modo de entender, por ejemplo, "la niñez", "la feminidad", etc. Así explica que cuando vemos una foto de un niño vestido de determinada manera, no significa necesariamente que estemos viendo el modo en que los niños se vestían en esa época. Lo que veríamos - siempre siguiendo a Burke- es el modo en que se concibe la niñez y por lo tanto se la representa de tal manera: "Las imágenes dan acceso no ya directamente al mundo social, sino más bien a las visiones de ese mundo propias de una época, a la visión masculina de la mujer, a la visión de los campesinos que tiene la clase media, etc." (238). La segunda medida que propone es la de la seriación: "El testimonio de una serie de imágenes es más fiable que el de una imagen individual" (239). Dicha "serie" puede ser entendida de dos maneras: como una serie de fotos de un mismo tiempo y espacio o una serie de fotos que impliquen cambios en un largo plazo, lo que se denomina como "historia serial". Para dar un ejemplo, en el primer caso se trataría de varias fotos de la Fiesta de la Tirana de 2015. En el segundo caso, y siguiendo con el mismo ejemplo, se trataría de fotos de la Fiesta de la Tirana del año 2010, 2011 y 2012. Ambas medidas expuestas -la contextualización (en sus variaciones) y la seriación- pretenden ser un modo prudente de leer la fotografía, potenciando su rasgo de imagen documental y reduciendo el margen de arbitrariedad.

\section{Tercera modalidad: montaje de un dispositivo contextual}

Para esta tercera aproximación retomamos dos artículos reunidos en La política de las Imágenes, conjunto de estudios dedicados a la obra del artista chileno Alfredo Jaar: "La emoción no dice yo. Diez fragmentos sobre la libertad estética" de Georges Didi-Huberman y "El teatro de imágenes" de Jacques Rancière. Partamos por Didi-Huberman.

Didi-Huberman plantea una crítica a la imagen televisiva, suscribiéndola a la categoría de información. Bajo este criterio la imagen no dice nada, ya que constituye un cliché o lugar común o bien dice demasiado, en la medida en que repite e inunda al espectador de imágenes saturantes. Para escapar de esta aporía de la imagen, Didi-Huberman postula una imagen de la contrainformación en la cual el sujeto que mira se vería inserto en un juego doble de la mirada. A esta doble distancia también se le denomina arte equilibrista, debido a que el sujeto oscilaría entre dos polos. Un primero en el que el sujeto se ve afectado emocionalmente por la foto, pero no posee una distancia crítica que lo lleve finalmente a una postura ética. Un segundo polo en el que desarrolla una lectura extremadamente distanciada y ana- 
lítica que lo mantiene ajeno a las implicancias de la imagen. Ante ambos extremos, Didi-Huberman propone un juego de "implicación / explicación": La imagen exige de nosotros, cada vez - un arte equilibrista: enfrentar el peligroso espacio de la implicación en el que nos desplazamos con delicadeza, corriendo el riesgo, a cada paso, de caer en la creencia, en la identificación; mantener el equilibrio [...] ayudándose con la vara de la explicación (de la crítica, del análisis, de la comparación) ("La emoción no dice yo" 43).

La explicación y la implicación, aparentemente, serían movimientos contrarios. Lo que se busca es un doble ejercicio complejo y paradójico, una "comprensión implicativa": No solamente el conocimiento en sí mismo supone momentos de emoción, algunas cosas -las cosas humanas- sólo son susceptibles de interpretación y de explicación a través del procedimiento necesario de una comprensión implicativa [...] el objeto del conocimiento, en ese mismo momento, se reconoce al estar íntimamente implicado en la construcción misma del sujeto que conoce (45).

Esto que parece paradójico, no lo es tanto si se entiende de modo temporal o secuencial. Si seguimos bien a Didi-Huberman, primero viene la implicación y luego la explicación. Dicho de otro modo, la explicación obedece a una implicación que la origina: "consistiría más bien en fundar esa explicación, su racionalidad misma, en la mirada y la emoción en que se trama esa experiencia" (46). Didi-Huberman ejemplifica este doble movimiento en el trabajo del fotógrafo chileno Alfredo Jaar a partir de su viaje a África para fotografiar y testimoniar el increíble genocidio en Ruanda ${ }^{6}$. El espectador de esas fotografías permanecería ajeno a la experiencia más abarcadora del viaje, es decir, de las emociones, de las palabras del artista: "Las fotografías suponían un proceso, no funcionaban sin el viaje mismo [...] Así, para explicar -así para que eventualmente un aficionado al arte, en una galería, tuviera que enfrentar íntimamente esa situación- se necesitaba implicar ese proceso, esas emociones, esas palabras [...] en la presentación de las imágenes mismas" (48).

La propuesta de la implicación, tal y como la presenta Didi-Huberman, no deja de ser criticable o al menos cuestionable desde algunos principios de la hermenéutica. Si abarcamos el fenómeno artístico en sus tres momentos -el de la creación, el de lo creado y el de su recepción- esta postura sugiere acercar la recepción a la creación. La propuesta de la "implicación" se nos presenta como problemática ya que reflota el viejo conflicto hermenéutico de la "distancia temporal". Hans-George Gadamer piensa este problema en el capítulo titulado "El significado hermenéutico de la distancia en el tiempo" en su Verdad y Método. Gadamer establece un diálogo crítico con la

6 En el año 1994, el gobierno de Ruanda lleva a cabo una política de exterminio de la población tutsi, se calculan alrededor de 800.000 los asesinados. 
tradición hermenéutica romántica, la que frente a la distancia temporal que separa al "lector-intérprete" del texto, sostiene la necesidad de "acortar" esa distancia. Es decir, un movimiento o desplazamiento hacia el momento de la creación. Esto choca con el principio fundamental de que "cada texto debe ser comprendido desde sí mismo" (361). Pero, ¿qué hacer con la distancia temporal? Ya decíamos que Gadamer critica duramente el intento por "retroceder" en el tiempo y sumergirse en el autor o el momento de la creación. De la hermenéutica romántica afirma: "Recordaremos que ésta pensaba la comprensión como la reproducción de una producción originaria. Por eso podía colocarse bajo la divisa de que hay que llegar a comprender a un autor mejor de lo que él mismo se comprendía" (366). ¿Es acaso esto lo que propone Didi-Huberman? ¿Habremos de "viajar" a Ruanda con Alfredo Jaar? ¿Entrar en su mente? Esto podría conducir a una especie de "acto adivinatorio". Cito nuevamente a Gadamer: "No es sino muy consecuente que la teoría de la comprensión culmine, en Schleiermacher, en una teoría del acto adivinatorio mediante el cual el intérprete entra de lleno en el autor y resuelve desde allí todo lo extraño y extrañante del texto" (363). Jacques Rancière, en su estudio recopilado en el mismo texto sobre Alfredo Jaar, nos da más luces sobre el concepto de implicación.

Lo que propone Rancière, en consonancia con Didi-Huberman, es la necesaria contextualización de la imagen fotográfica. La diferencia con la contextualización ya mencionada de Burke, es que esta no es tan solo de tipo histórico-epocal, es decir, una mera información: se trata de una contextualización espacio temporal, sensorial, que permita la deseada implicación propuesta por Didi-Huberman. Expliquemos esto. Siguiendo con la obra fotográfica de Alfredo Jaar, Rancière cita una frase del artista chileno en que sostiene: "es preciso [...] acompañar los mensajes y las imágenes de su contexto” (85). A renglón seguido Rancière se pregunta: “¿qué debemos entender, en realidad, por ese contexto?" (85). Y contesta: "Se trata de construir un espacio en el cual un tejido inédito de palabras y formas pueda dar una resonancia a la muerte masiva" (85). No es, entonces, una información o dato histórico; no es, tampoco, un ir hacia el momento de la creación originaria al estilo de un "historicismo ingenuo". Hay que entender el espacio aludido de un modo literal: es la inserción de la fotografía el interior de una arquitectura, de una intervención creada para la recepción implicativa.

La obra fotográfica demandaría de una nueva creación para su recepción. Ejemplo de esto es la obra de Jaar denominada The Sound of Silence. Es necesario

7 En relación a este problema, María Paz Bajas en su artículo "La transfiguración de la imagen. El artista, su obra y el espectador" expone un interesante uso del "viaje hacia el pasado" y su posible manipulación. Bajas analiza la utilización que se hace en Archipiélago (película de Pablo Perelman) de las imágenes del film previo de Alberto María De Agostini de los indígenas fueguinos. Perelman introduce las imágenes más antiguas de los indígenas para así gatillar en el espectador una determinada recepción del sujeto indígena. Se lleva al espectador, mediante esta "transfiguración" a un pasado anacrónico: "el realizador nos hace viajar del presente al pasado". Mediante esta técnica "el realizador ejerce cierto control sobre el espectador en torno al conocimiento previo, pues se lo instrumentaliza instalándole un determinado imaginario cultural". 
explicar brevemente en qué consiste esta obra. Jaar utiliza una única fotografía, la del fotógrafo sudafricano Kevin Carter, la de la niñita al borde de la inanición y el buitre acechándola. Carter fue, en su momento, sumamente criticado por esta fotografía y posteriormente se suicida. ¿Qué hace Jaar con esta foto? Construye un espacio cerrado de cientoveintiocho metros cúbicos, como una casa blanca, se entra a ella luego de la indicación de una luz verde en su entrada. Al interior le esperan al visitante palabras como estrofas de poemas que cuentan el viaje de Carter, la toma de la fotografía, su suicidio, y finalmente, aparece la fotografía de la niña ruandesa. La estadía en este espacio dura ocho minutos. Este procedimiento es, hasta cierto punto, una contextualización como la entiende Peter Burke: del autor y del momento de la foto. Pero es más que eso, Rancière sostiene:

No se intenta, por supuesto, imitar la situación del reportero fotográfico comprometido, confrontando el hambre en el desierto sudanés. Se trata de construir un dispositivo espacio-temporal de visión, sustrayéndolo tanto al espacio del periódico como a la instalación museística de fotografías en gran formato, un dispositivo que comprometa por sí mismo una experiencia sensorial excepcional (87).

Entendemos esta contextualización tanto desde las concepciones gadamerianas de la hermenéutica como desde las concepciones de tiempo y espacio de Paul Ricoeur. Según Gadamer, "cuando intentamos entender un texto no nos desplazamos hasta la constitución psíquica del autor, sino que, ya que hablamos de desplazarse, lo hacemos hacia la perspectiva bajo la cual el otro ha ganado su propia opinión" (361). El dispositivo material descrito por Rancière puede ser esa perspectiva y puede logar la implicación, o en términos gadamerianos, la participación: "es tarea de la hermenéutica explicar este milagro de la comprensión, que no es una comunión misteriosa de las almas sino participación en un sentido comunitario" (362). Rancière también hace hincapié en los sentidos, en el espacio y en el tiempo, coordenadas todas que definen la experiencia humana. Entendemos ese dispositivo como un intento de insertar la fotografía dentro de un marco narrativo mayor que posibilite tanto su comprensión como la elaboración de una experiencia. Tal y como Paul Ricoeur entiende la experiencia, ligada a un entramado que organiza la temporalidad: "Veo en las tramas que inventamos el medio privilegiado por el que re-configuramos nuestra experiencia temporal confusa, informe y en el límite, muda" (34). La mudez que Burke le adjudicaba a la fotografía podría, así, convertirse en una narración con sentido. Resumiendo, la contextualización e implicación de la que aquí se habla vendría siendo un modo de superar la distancia del tiempo mediante la apelación a coordinadas temporales y espaciales. 


\section{Pensando las tres lecturas en Fotografía. El arte de visibilizar la pregunta de Koen Wessing}

La obra de Koen Wessing ${ }^{8}$ se expuso hace pocos años en el Centro Cultural Gabriela Mistral (2011), y este libro contiene dicha muestra dividida en tres partes, las que se titulan sucintamente: “Chile 1973", "Nicaragua 1978” y "El Salvador 1980”. El libro consta casi exclusivamente de fotografías ${ }^{9}$ sin texto a pie de página que pueda guiar al lector. Es por eso que este "texto fotográfico" plantea, en su desnudez, tan urgentemente la pregunta por el modo de leerlo. Es distinto el caso de obras intermediales en las que foto y palabra entran en diálogo, u obras en las que la fotografía se inserta dentro de un texto que la acoge. Un buen ejemplo de trabajo intermedial encontramos en Alto el Perú de Julio Cortázar y Manja Offerhaus; o El infarto del alma, de Diamela Eltit y Paz Errázuriz. En el caso de “fotografía más texto a pie de página”, un buen ejemplo es el de Bertolt Brecht y su $A B C$ de la Guerra. Si traigo a colación estos libros es precisamente para realzar la radicalidad de la obra de Wessing: el trabajo de Wessing es estrictamente fotográfico. Quizás, lo que más realza la pregunta por la modalidad de lectura es el hecho de que la editorial Lom haya apostado por la publicación bajo el formato de un libro. Concretamente, en el caso de "Chile 1973", se trata de 42 fotografías en blanco y negro que ocupan espacialmente casi la totalidad de la página. A modo de "introducción” y como único texto escrito, al comienzo de “Chile 1973” se lee en hoja aparte:

Apenas se entera del golpe de Estado contra Salvador Allende, Wessing viaja a Santiago. Fotografía las calles del centro, a gente que llora o que solo mira, a los militares que trasladan detenidos, revisan y custodian transeúntes, requisan y queman libros y revistas. Registra el funeral de Pablo Neruda. Logra retratar a altos mandos militares y entrar al Estadio Nacional, transformado en campo de prisioneros. Allí, con la comprensión del fumador empedernido, intenta convidarles cigarrillos a los detenidos: capta el momento en que un prisionero y un soldado se disputan los cigarrillos tirados en el suelo (7).

De las 42 fotos hemos escogido dos para pensar con ellas las tres aproximaciones expuestas (figs. 2 y 3 ).

8 Koen Wessing (1942-2011) fue un fotoperiodista de origen holandés que se dio a conocer por sus variados trabajos en zonas de conflicto.

9 Al comienzo hay una breve reflexión titulada "Volver a pasar por el corazón", escrita por la editora Silvia Aguilera y al final de todas las fotos (Chile 1973/Nicaragua 1978/El Salvador 1980) hay otro breve texto titulado "Posfacio" de Johan van der Keuken. La editora considera que las fotos se constituyen en un cuerpo: "destacan en ellas las miradas de interpelación o desolación, el sufrimiento, el miedo; el grito mudo del dolor, de la rabia e impotencia; la dignidad; la perseverancia, la resistencia, la búsqueda; la destrucción, la barbarie, la prisión, la larga espera, la muerte y, pese a todo, la vida" (5). Van der Keuken en su Posfacio, texto que en realidad fue escrito para la publicación De Chile a Guatemala. Diez años en América Latina (Hammer, Holanda, 1983), destaca la capacidad de interpelación en la fotografía de Koen Wessing: "Entonces uno descubre que ha sido personal y físicamente tocado por su mirada y surge una pregunta por cada persona y cada cosa que aparece en la imagen" (105). 
FIGURA 2

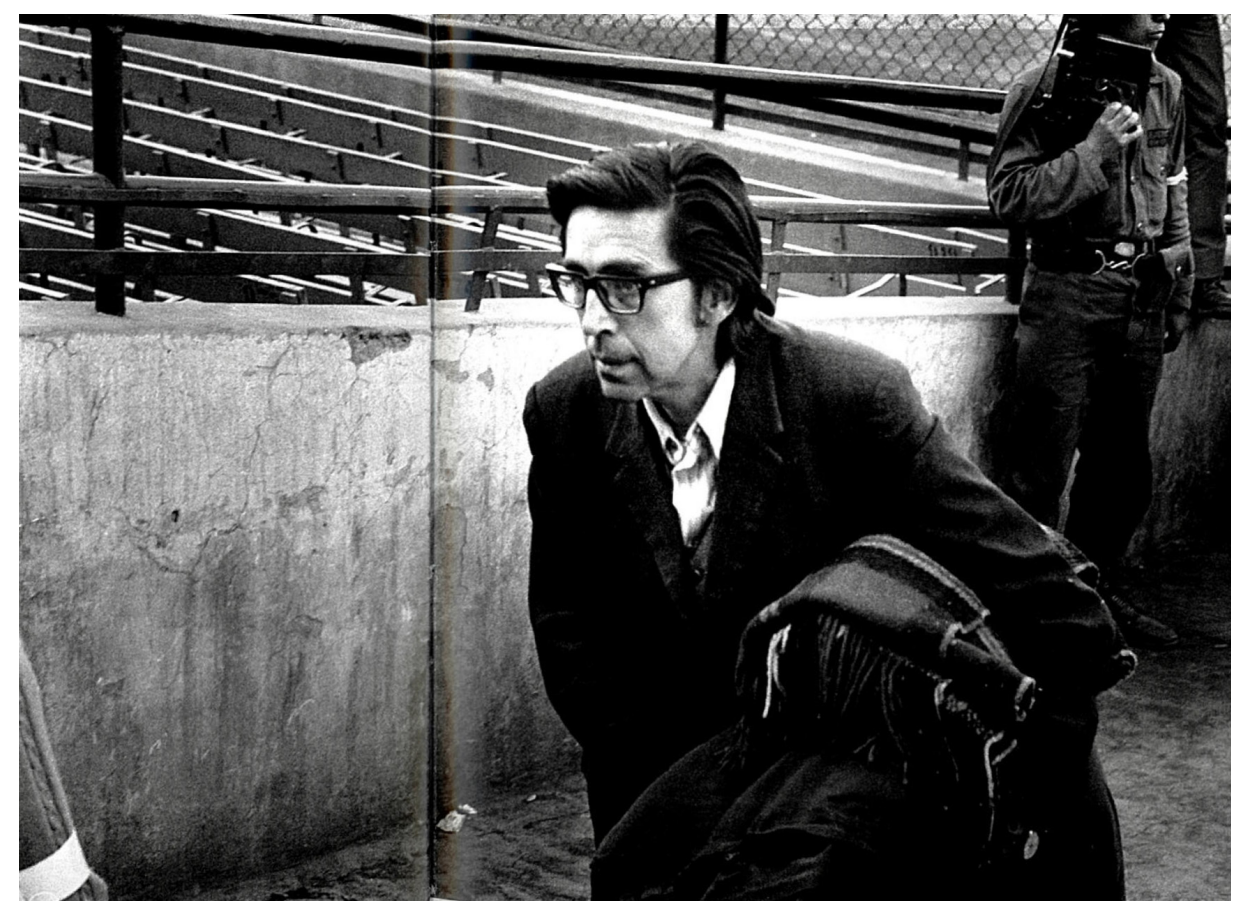

Hombre con lentes y frazada.

FIGURA 3

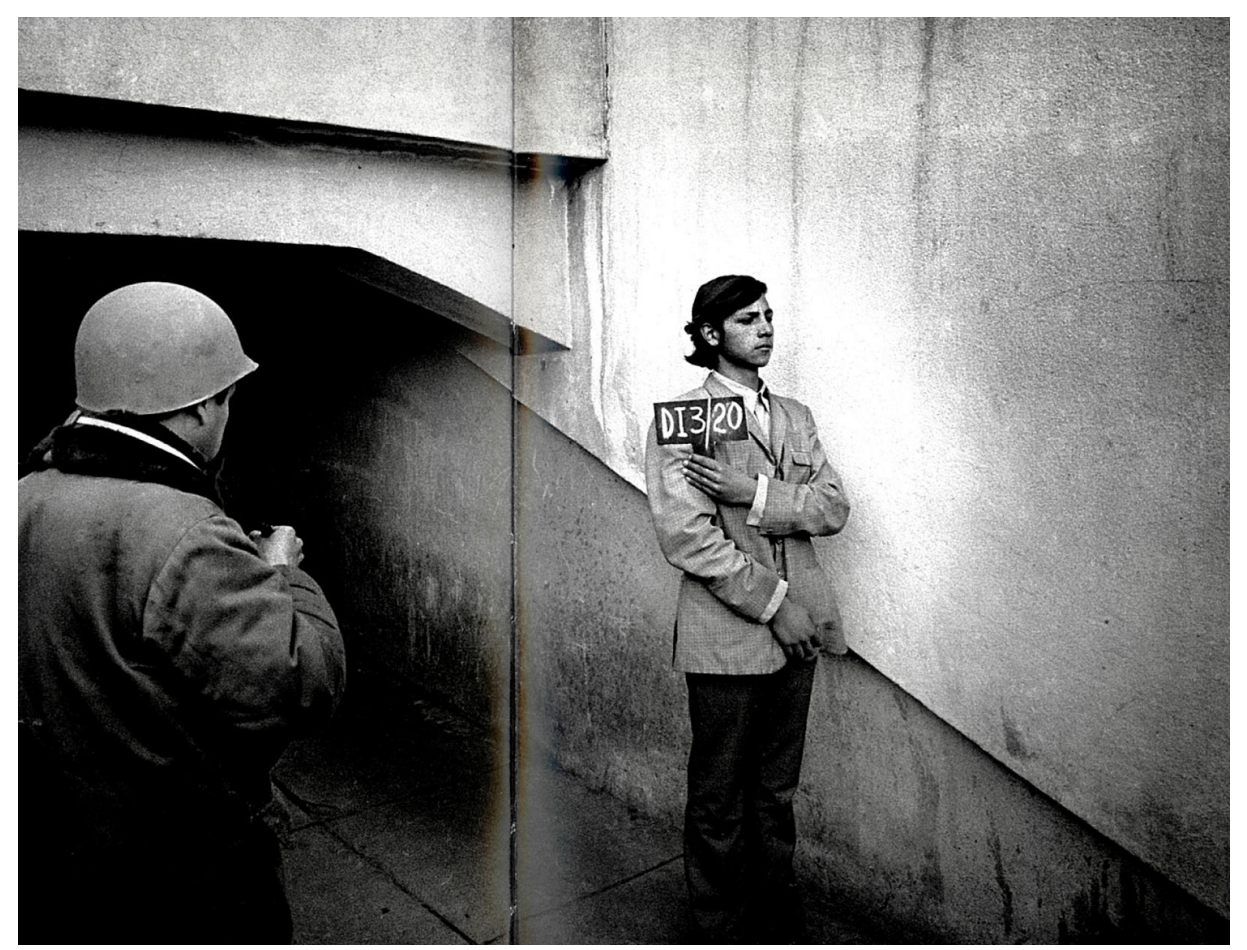

Joven con cartel de identificación. 


\section{Lectura descontextualizada (fig. 2)}

Un hombre está evacuando el estadio, hubo una bomba o amenaza de bomba y los soldados ayudan en este proceso a mantener el orden y la calma. El señor había llevado una frazadita para ver el partido con comodidad. El lector proyecta una lectura aparentemente sin asidero y construye un relato que nada tiene que ver con la realidad ${ }^{10}$. El problema es que -y aquí vuelvo a Cortázar- dicha lectura se realizó a partir de elementos estructurales presentes en la obra, no es una invención: ahí está la frazada y ahí está el señor como escapando. Por lo tanto, más que rechazar de plano esta lectura, importa hacerse cargo de ella. Incluso si nos apegamos más a un contexto referencial, esta misma fotografía puede apoyar una lectura promilitar. La presencia de la frazada es señal clara de lo bien tratados que estaban los prisioneros, y los lentes del señor indican que se les permitía la lectura y el cultivo del espíritu durante su detención. Lo mismo con la segunda foto escogida: el joven está siendo inscrito, es decir, los procedimientos de detención no fueron arbitrarios: se llevó a cabo un claro y abierto registro de las detenciones. Nos enfrentamos al problema de la manipulación, una foto del todo descontextualizada puede más fácilmente ser manipulada. En relación a la manipulación, Joan Fontcuberta posee una postura extrema, sostiene que toda fotografía es manipulación de la real: "la fotografía pertenece al ámbito de la ficción mucho más que al de las evidencias. [...] La fotografía es pura invención” (116). Si bien Fontcuberta es lapidario en su juicio ${ }^{11}$, se podría decir que siempre ha existido una lucha entre las posturas claramente proicónicas de la fotografía y las más indiciales. Independiente de si consideramos a la fotografía "ícono" o "índice", en ambos casos, la descontextualización abre paso a la posibilidad de la manipulación.

10 Es cierto que algunos teóricos extremos sostienen, precisamente, que la fotografía nada tiene que ver con la realidad y, por ende, con la verdad. Sin entrar en un debate teórico sobre el punto, aquí sostenemos que, en gran medida, la implicación buscada por Rancière y Didi-Huberman, se produce debido y gracias al carácter indicial y referencial de la fotografía. Conocida es la división tripartita del signo en ícono (analogía), huella (índice) y símbolo (convención). Santos Zunzunegui analiza cuál sería la categoría más propicia para la imagen fotográfica y baraja argumentos a favor y en contra de cada categoría. Lo central es que detrás de la problemática se dejan ver dos posturas básicas. La primera concibe a la fotografía como copia de la realidad y objetivamente. La segunda, la concibe como independiente de la realidad y arbitraria. En apoyo de la primera postura se cita a Gombrich quien sostiene "grados de iconicidad" y a Barthes con su "estuvo ahí". A favor de la segunda postura se menciona a Gubern (la fotografía elimina elementos sensoriales, reduce la tridimensionalidad, posee un punto de vista, etc.), a Eco (la foto puede mentir) y a Berger (capacidad de la foto para intervenir). A favor de la fotografía como símbolo, Concha, en un minucioso recorrido teórico en su artículo "Imagen fotográfica y lenguaje", señala: "En resumen la fotografía será un tipo de signo especial que llamaremos símbolo (Ricoeur 1975) y que nos remite a una ficción, esta ficción (imagen fotográfica) toma forma a partir de las particularidades técnicas, la que se materializa en la gama de grises que van del blanco al negro, y remite a un mundo creado por el fotógrafo" (271).

11 Su postura radical se sintetiza en la siguiente cita: "El arte contemporáneo ahonda en esta idea de falsificación como estrategia intelectual. Detrás del juego y la provocación se esconde una sátira sobre el rol que la fotografía debe asumir hoy. ¿Es todavía una tecnología al servicio de la verdad, un soporte de evidencias? Hoy ya nada es evidente; por el contrario, navegamos a través de la nebulosa de la ambigüedad, de espacios virtuales que sustituyen la experiencia. En el contexto de la cultura de los media, los conceptos de verdad y falsedad han perdido cualquier validez. Todo es verdadero y falso a la vez. Lo cual impone un nuevo protocolo de relación con la imagen y los sistemas de transmisión de conocimiento, que tiende tanto a reposicionar las funciones sociales de las tecnologías productoras de imágenes como a redefinir la noción de lo real” (122). 


\section{Lectura contextualizada}

En el caso de Chile 1973 y las detenciones arbitrarias, la contextualización a la manera de Burke sería necesariamente la información histórica acerca de los detenidos: el cómo, el cuándo, el dónde, el porqué y los acontecimientos antes, durante y después de las detenciones. Lo que equivaldría a recurrir a otros documentos, sobre todo textos, ya sea históricos o literarios/testimoniales. También, si Burke incluye el momento de la producción como contextualización, se debería incluir información acerca del golpe y del momento político que el país atravesaba. La visión del propio Koen Wessing acerca de su trabajo y las condiciones en que fueron tomadas las fotografías también serían parte de una contextualización. Todo esto implica un libro o al menos un pequeño folleto acompañando cada fotografía. Si la fotografía necesita de un texto, entonces, ¿para qué la fotografía? La función documental de la fotografía también ha sido fuertemente cuestionada en los teóricos más posmodernistas (Fontcuberta). Pero si seguimos posturas más moderadas, la fotografía, acompañada o acompañando a otras fuentes de información, puede, aún en tiempos de cuestionamientos, ser fuente de información. Luis Lara López, por ejemplo, criticando la primacía del texto escrito, propone una relación complementaria para ambas fuentes:

Este discurso histórico debería replantearse desde la asunción de las inmensas posibilidades de información que contienen las imágenes, mandando al ostracismo la concepción jerárquica que primaría la palabra sobre lo visual, que se cimentaría en una oscura percepción sobre una especie de debilidad innata de la imagen a la hora de comunicar, y en el ámbito de las Humanidades/Ciencias Sociales, las relaciones entre fotografía y palabra deben pasar de términos de subsidiariedad a complementariedad, ya que estas interrelaciones posibilitan contextualizar adecuadamente la imagen fotográfica a través de la palabra (8-9).

Veamos ahora el segundo modo de contextualizar señalado por Burke, el de la seriación, es decir, una serie de fotos de un mismo tiempo y espacio. No resulta tan evidente distinguir "series" al interior de estas 42 fotos. Sin embargo, ateniéndonos a un criterio espacial más que temporal (¿cómo comprobar el tiempo de la foto sin acudir al emisor/fotógrafo?) se pueden reconocer al menos tres series: la de los militares revisando a personas en las calles de Santiago, la de los detenidos en el Estadio Nacional y la de la quema de libros en la calle por parte de los militares. De estas tres la que mayor unidad posee es la de la quema de libros. Consta de seis fotos en las que el encuadre juega un rol central, se va desde un plano general muy amplio (militares trasladando libros) hasta un encuadre en primerísimo plano de un ejemplar de la revista Punto final ardiendo en llamas con el rostro de Allende en portada. En la serie del Estadio Nacional hay fotos de su interior con detenidos siendo "inscritos", otras del exterior del Estadio y algunas de los presos recibiendo cigarrillos. Si bien la seriación aporta a la veracidad del acontecimiento y la repetición reafirma su estatuto de acon- 
tecimiento, es difícil realizar a cabalidad un análisis de tipo narrativo. Entendiendo por narrativo el reconocimiento de estructuras -siguiendo a Roland Barthes- tales como "secuencias", "funciones", "acciones", "catálisis", etc. ${ }^{12}$ Salvo el caso de la quema de libros las series son una variación de fotos de un mismo espacio más que un ciclo que funcione como relato. Por eso recalcamos por sobre todo el valor de "fiabilidad" que las débiles series otorgan a los acontecimientos. En síntesis, el trabajo de Wessing en "Chile 1973", correctamente contextualizado (época, autor, fotos en serie), podría ayudar a tener una mejor perspectiva sobre los acontecimientos en cuestión.

\section{Lectura con dispositivo contextual}

Si asumimos que el formato libro no sería el mejor espacio generador de una contrainformación -es decir de una implicación del observador que lo lleve a una reflexión y respuesta ética- entonces nos preguntamos por ese espacio adecuado. ¿Cuál sería el espacio arquitectónico para esta fotografía? Muchas de ellas fueron tomadas en el Estadio Nacional ${ }^{13}$. Es por eso que pensamos que el propio Estadio Nacional podría generar esa implicancia buscada. Sé que esta respuesta es de inmediato criticable, ya advertía Rancière en relación a las fotos de Jaar de Ruanda que no se trata de "pretender hacernos sentir como si estuviésemos allí, ante la carnicería ruandesa" (85). Rancière ocupa la palabra "resonancia" y por eso pienso que el espacio temporal del Estadio puede crear esa resonancia en la que la fotografía vibre de un modo más cargado de significación. Si la experiencia temporal y sensorial contextualiza la foto, el Estadio Nacional ofrece todos esos elementos. Ahora bien, el formato libro tiene sus ventajas, un libro puede ser releído cuántas veces se quiera. A su vez, esa lectura del libro puede insertarse en distintos espacios y tiempos: un tranquilo atardecer en la comodidad del living, una apresurada ojeada en la oficina, etc. Los espacios de lectura también juegan un papel en la recepción de una obra "tradicional". Pero si lo que se busca es esa intimidad, ese acercamiento al momento de la creación, el espacio del Estadio Nacional podría jugar un papel importante en la medida en que intensifica las coordenadas temporales y espaciales. El tiempo se intensifica ya que obligaría a una ralentización de la experiencia, aumentando la duración de la actividad. Y el elemento espacial puede llevar a un mayor compromiso sensorial en la medida en que el sujeto participa física y presencialmente en su desplazamiento por el espacio de las

12 Un análisis narrativo de una serie de imágenes es ciertamente posible, pero para ello es necesario una mayor ligazón tanto de efecto-causa entre las imágenes como una cadena de acciones, lo que no es el caso en el trabajo de Wessing. Un ejemplo de esta lectura narrativa de imágenes la encontramos, por ejemplo, en el artículo de Felipe A Maturana: "El documental fueguino chileno en el siglo xxi. Una mirada desde la antropología visual" (2006). Maturana, siguiendo algunos principios de Eisenstein y Todorov, entre otros, analiza narrativamente tres documentales: "La última huella" (Paola Castillo), "Nosotros somos los Selk'nam" (Christian Aylwin) y "Estrecho de Magallanes" (Hernán Dinamarca).

13 El Estadio Nacional, luego del golpe militar contra el gobierno de Salvador Allende, fue utilizado como lugar de detención y tortura. Se calcula que por sus “celdas" pasaron cerca de 40.000 detenidos. 
fotografías. Hay un elemento aurático que obviamente se añadiría en la experiencia, debido a la carga histórica del Estadio Nacional. Precisamente, una de las definiciones dadas para aura es: "una trama singular de espacio y tiempo" (Didi-Huberman, Lo que vemos: 97). La implicancia propuesta por Didi-Huberman y Rancière, ciertamente, se acerca bastante a esta concepción benjaminiana de aura. Ahora bien, la pregunta por el espacio preciso para la lectura de una fotografía es sumamente compleja. El montaje de un dispositivo contextual busca una respuesta tanto emotiva como intelectual y entramos así en los terrenos de una recepción, más que los de una producción: ¿cómo "verifico" que la implicancia ha tenido lugar?

De la revisión hecha hasta el momento, nada nuevo en el fondo. Todo se puede reducir a viejos principios teóricos, válidos tanto para una novela como para una fotografía. Todo "texto" puede ser leído-interpretado haciendo énfasis en uno de los tres momentos que conforman todo proceso de comunicación: el mensajero (artistafotógrafo), y entonces la contextualización epocal; el mensaje (la fotografía), que se refiere al análisis semiótico y decodificador; o el receptor (lector/veedor), en que se enfatiza la experiencia estética/ética. Cada una de estas aproximaciones tiene ventajas y desventajas y es muy probable que la mejor lectura sea aquella que utilice sabiamente un poco de cada una. Y, sin embargo, estas conclusiones no me satisfacen de ninguna manera. ¿Es acaso el texto fotográfico reducible en su "particularidad" o "especificidad" a las mismas lecturas tradicionales de un texto escrito? Me niego a creer esto. Hay en la fotografía una experiencia única, distinta, ligada precisamente a su visualidad, a su materialidad. Pero hacer hincapié en esta experiencia sería caer en lecturas un tanto místicas del tipo barthianas, centradas en el "esto ha sido" y la presencia de huella, en el punctum, en el enamoramiento ${ }^{14}$. Y sí, sucede que, efectivamente, estoy enamorada del muchacho de la fotografía de Wessing, del muchacho del cartelito Di3/20 (de su peinado, de su ceño fruncido, de la posición de sus manos, de sus zapatos). Y como precisamente tengo el contexto en mi cabeza, y sé lo que le va a pasar/lo que le pasó, como precisamente la fotografía me demanda un juego de implicación/explicación (Didi-Huberman), es que quiero, deseo, en una "implicancia" tanto ética como sensible, que nada de eso hubiera pasado, que nada de eso siga pasando. Y entonces, si he de concluir, finalizo con el título del propio Koen Wessing: la fotografía es el arte de visibilizar la pregunta ${ }^{15}$, y las preguntas aquí son: ¡pero, cómo! ¡Por qué! ¿Cómo "nunca más”?

14 De hecho, Roland Barthes, en su ineludible estudio sobre la fotografía, La cámara cúcida, afirma en varios momentos ese "estar enamorado" y reconoce ese elemento pasional como inicio o punto de partida para su reflexión. En la segunda parte se nos confiesa el origen velado de La cámara lúcida, nos referimos a la foto de su madre cuando pequeña en el invernadero y el amor que siente por ella.

15 Volviendo a la discusión abierta más arriba sobre el problema de "la distancia en el tiempo", precisamente, Gadamer considera que la distancia es positiva en la medida en que abre paso a las preguntas adecuadas: "la posibilidad de adquirir una cierta panorámica sobre un proceso histórico en virtud de su carácter relativamente cerrado sobre sí, de su lejanía respecto a las opiniones objetivas que dominan en el presente, todo esto son hasta cierto punto condiciones positivas de la comprensión histórica" (368). Cuando Koen Wessing define a la fotografía como "el arte de visibilizar la pregunta" lo entendemos como ese camino hermenéutico en el que, gracias al paso del tiempo, el intérprete puede iniciar el proceso de diálogo dirigido con la obra. Y la "esencia de la pregunta es el abrir y mantener abiertas posibilidades” (369). La fotografía abre este diálogo con ese pasado desde un diálogo menos prejuicioso. 


\section{Referencias}

Bajas, María Paz. "La transfiguración de la imagen. El artista, su obra y el espectador". Magallania 34.2 (2006): 11-20. Impreso.

Burke, Peter. Visto y no visto. El uso de la imagen como documento histórico. Barcelona: Crítica, 2005. Impreso.

Concha, José Pablo. "Imagen fotográfica y lenguaje”. Aisthesis 34 (2001): 264-273. Impreso.

Cortázar, Julio. Historias de cronopios y de famas. Buenos Aires: Sudamericana, 1986. Impreso.

Didi-Huberman, Georges. "La emoción no dice yo. Diez fragmentos sobre la libertad estética”. La política de las imágenes. Ed. Adriana Valdés. Santiago: Metales Pesados, 2008. 39-52. Impreso.

---. Lo que vemos, lo que nos mira. Buenos Aires: Manantial, 1997. Impreso.

Fontcuberta, Joan. El beso de Judas. Fotografía y verdad. Barcelona: Gustavo Gili, 2011. Impreso.

Gadamer, Hans Georg. Verdad y método. 2 vols. Salamanca: Sígueme, 2003. Impreso.

Lara, Emilio. "La fotografía como documento histórico-artístico y etnográfico: una epistemología”. Revista de Antropología Experimental 5 (2005): 2-28. Impreso.

Maturana, Felipe. "El documental fueguino chileno en el siglo xxi. Una mirada desde la antropología visual". Magallania 34 (2006): 59-75. Impreso.

Ricoeur, Paul. Tiempo y Narración, vol. 1. México: Siglo xxi, 2004. Impreso.

Rancière, Jacques. "El teatro de imágenes". La política de las imágenes. Ed. Adriana Valdés. Santiago: Metales Pesados, 2008. 69-89. Impreso.

Valdés, Adriana, ed. La política de las imágenes. Santiago: Metales Pesados, 2008. Impreso.

Wessing, Koen. La Fotografía. El arte de visibilizar la pregunta. Santiago: Lom, 2011. Impreso.

Zunzunegui, Santos. Pensar la imagen. Madrid: Cátedra, 1998. Impreso.

Recibido: 23 noviembre 2015 